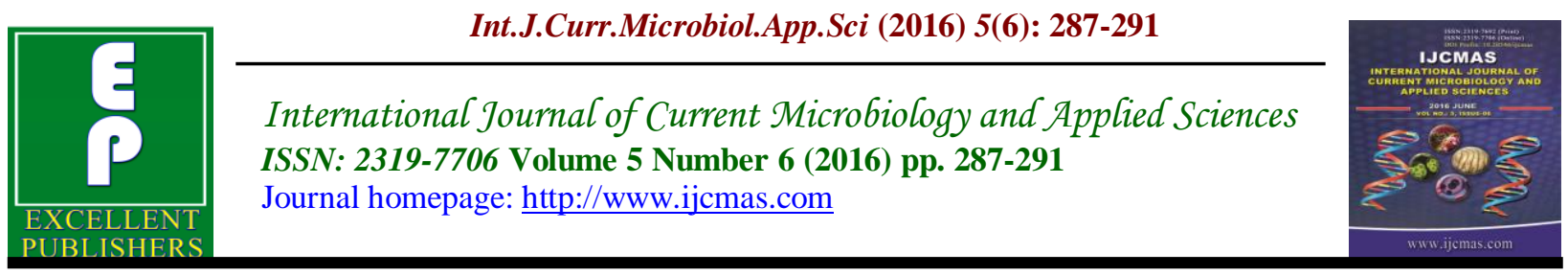

Original Research Article

http://dx.doi.org/10.20546/ijcmas.2016.506.032

\title{
FT-IR Spectroscopic Studies on Flowers of Allamanda neriifolia Hook
}

\author{
R. Sumathi* and R. Anuradha \\ Department of Biochemistry, Rabiammal Ahamed Maideen College for \\ Women, Thiruvarur, India \\ Department of Biochemistry, S.T.E.T. Women's College, Mannargudi, Tamilnadu, India \\ *Corresponding author
}

\section{Keywords}

FT-IR, Allamanda neriifolia hook, Functional groups, and Bioactive compounds.

\section{Article Info}

Accepted:

15 May 2016

Available Online:

10 June 2016
A B S T R A C T

The present study was carried out to investigate the methanolic extracts of flowers of Allamanda neriifolia hook through FT-IR spectroscopy method. The FT-IR spectroscopic studies revealed different characteristic peak values with various functional compounds in the extracts. The FT-IR analysis of methanolic extracts of Allamanda neriifolia hook confirmed the presence of phenols, alkanes, alkynes, aromatics, aromatic and aliphatic amines and alkyl halides which showed a major peak values. The FT-IR method was performed on a spectrophotometer system, which was used to detect the characteristic peak values and their functional groups.

\section{Introduction}

Medicinal plants play a pivotal role in the health care of ancient and modern cultures. Ayurveda, the Indian system of medicine mainly uses plant based drugs or formulations to treat various human ailments because they contain the components of therapeutic value. In addition, plant based drugs remain an important source of therapeutic agents because of the availability, relatively cheaper cost and non-toxic nature when compared to modern medicine (Nithya Narayanaswamy and Balakrishnan, 2011; Agbor and Ngogang, 2005).

Plants are an important source of organic antioxidant chemicals which are widely used as ingredients in dietary supplement (Chaturvedi et al., 2015; Sowndharajan et al., 2011). Medicinal plants are of great importance to health of individuals and communities in general. The medicinal value of plants lies in some chemical substances that produce a definite physiological action on the human body (Puguh Surjowardojo, et al., 2014). Plants are endowed with various phytochemical molecules such as vitamins, terpenoids, phenolic acids, lignins, stilbenes, tannins, flavonoids, quinines, coumarines, alkaloids, amines, betalains and other metabolites which are rich antioxidant activity. These antioxidant compounds possess anti-inflammatory, anti- 
atherosclerosis, antitumour, antimutagenic, anticarcinogenic, antibacterial and antiviral activities (Herin Sheeba Gracelin et al., 2013).

The family Apocynaceae consists of several important medicinal plants with wide range of biological activities and interesting phytochemical constituents. Allamanda neriifolia Hook commonly known as the Yellow Bell, Golden Trumpet or The Buttercup flower is a genus of tropical shrubs and vines belonging to the family Apocynaceae. It has been used as a purgative or emetic, febrifuge as well as for the treatment of coughs, headaches, jaundice and enlarged spleen resulting from malaria. The milky sap is also known to posses antibacterial and possibly anticancer properties (Tiwari TN et al., 2002).

Fourier Transform Infrared (FTIR) Spectroscopy is a rapid, noninvasive, highresolution analytical tool for identifying types of chemical bonds in a molecule by producing an infrared absorption spectrum that is like a molecular fingerprint (Griffiths and De Haseth, 1986). FTIR has been shown to be a valuable tool for differentiating, classifying and discriminating closely related microbial strains, plants and other organisms (Helm et al., 1991). It is one of the most widely used methods to identify the chemical constituents and elucidate the structural compounds and has been used as a requisite method to identify medicines in Pharmacopoeia of many countries.

Preliminary phytochemical studies and GCMS analysis were already done by using this plant. Within a decade, there were a number of dramatic advances in analytical techniques, including FT-IR and GC-MS that were powerful tools for identification and determination of phytochemicals (Roberts and Xia, 1995). The present study was carried out to find out the active functional groups present in the flowers allamanda neriifolia hook in methanol extract with the aid of FT-IR techniques, which may provide an insight in its use of traditional medicine.

\section{Methods and Materials}

\section{Collection of Plants}

The selected medicinal plant Allamanda neriifolia hook was collected from Thiruvarur (Dt), Tamil Nadu, India. The flower was first washed well and dust was removed from the flower and were dried at room temperature .These dried materials were macerated to powder form with a mixer grinder and stored in air tight container for further use.

\section{Preparation of Extracts}

The coarsely powder was packed into soxhlet column and extracted with $70 \%$ methanol for 48 hours $\left(64.5-65.5^{\circ} \mathrm{C}\right)$. The extract was concentrated under reduced pressure (bath tem $50^{\circ} \mathrm{C}$ ) then the dried extract was stored in air tight container for further use.

\section{FT-IR Spectroscopic Analysis}

Fourier transform infrared spectrophotometer (FTIR) is perhaps the most powerful tools for identifying the types of chemical bonds (functional groups) present in compounds. Dried powders of different solvent extracts of each plant material were used for FTIR analysis. $10 \mathrm{mg}$ of the dried extract powder was encapsulated in $100 \mathrm{mg}$ of $\mathrm{KBr}$ pellet, in order to prepare translucent sample disc. The powdered sample of each plant specimen was loaded in FTIR Spectroscope (Shimadzu, IR Affinity1, Japan), with a scan range from 400 to 4000 
$\mathrm{cm}^{1}$ with a resolution of $4 \mathrm{~cm}^{-1}$ (Nithyadevi and Sivakumar., 2015).

\section{Results and Discussion}

FTIR analysis was used to identify the functional group of active components based on peak values in the region of infrared radiation. FTIR spectrum was analyzed and the results of FTIR spectrum profile was illustrated in the Fig 1, and tabulated in Table 1.

Table.1 FT-IR Peak Values of flowers of Allamanda neriifolia hook

\begin{tabular}{|l|l|l|l|}
\hline S.No & $\begin{array}{l}\text { Peak value } \\
\text { frequency } \\
\mathrm{cm}^{-1}\end{array}$ & Bond & Functional group \\
\hline 1 & 3370.98 & O-H stretch & $\begin{array}{l}\text { Alcohols/ } \\
\text { Phenols }\end{array}$ \\
\hline 2 & 2926.73 & C-H stretch & Alkanes \\
\hline 3 & 2364.22 & - & Unknown \\
\hline 4 & 2128.13 & $-\mathrm{C}=$ C-stretch & Alkynes \\
\hline 5 & 1642.56 & N-H bend & Primary amines \\
\hline 6 & 1407.99 & C-C stretch & Aromatics \\
\hline 7 & 1324.36 & C-N stretch & Aromatic amines \\
\hline 8 & 1242.43 & C-Br stretch & Alkyl halides \\
\hline 9 & 1051.88 & C-N stretch & Aliphatic amines \\
\hline 10 & 771.27 & NH bending & Amines \\
\hline 11 & 616.80 & $\begin{array}{l}\text {-C(triple } \\
\text { bond } \text { C-H:C- } \\
\text { H bend }\end{array}$ & Alkynes \\
\hline & & \multicolumn{2}{|l}{} \\
\hline
\end{tabular}

Fig.1 Shows the FT-IR spectrum of allamanda neriifolia hook

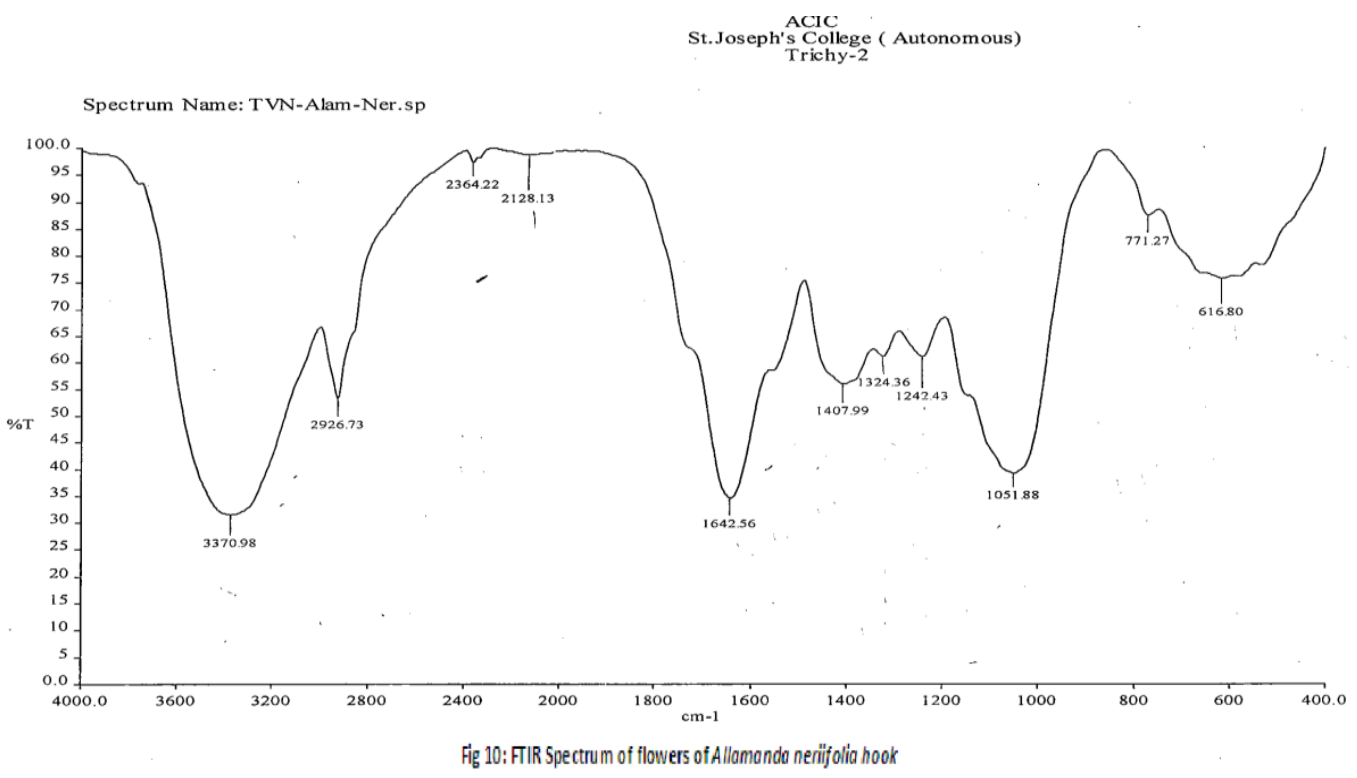


FTIR spectroscopic analyses was first reported on A.neriffolia revealed the presence of different functional groups of the bioactive compounds present in the A.neriifolia methanolic flower extract in the form of peaks. The functional groups were separated based on its peak ratio. The results of ftir spectrum shows a frequency range $3370.98 \mathrm{~cm}^{-1}$ representing the $\mathrm{OH}$ stretching and indicated the presence of alcohol and phenol. The peak obtained at $2926.73 \mathrm{~cm}^{-1}$ indicated the $\mathrm{C}-\mathrm{H}$ stretching presence of alkanes. The peak obtained at $2128.13 \mathrm{~cm}^{-1}$ and $616.80 \mathrm{~cm}^{-1}$ indicated the $-\mathrm{C}=\mathrm{C}$ - stretching and $-\mathrm{C}$ (triple bond) $\mathrm{C}$ $\mathrm{H}$ : $\mathrm{C}-\mathrm{H}$ bend and mainly the presence of alkynes. The peak obtained at $1642.56 \mathrm{~cm}^{-}$ ${ }^{1}$ indicates the $\mathrm{N}-\mathrm{H}$ bending presence of primary amines. The peak obtained at $1407.99 \mathrm{~cm}^{-1}$ indicates the C-C stretching presence of aromatic compound. The frequency range $1324.36 \mathrm{~cm}-1$ peak is representing $\mathrm{C}-\mathrm{N}$ stretching indicated the presence of aromatic amines. The peak obtained at $1242.43 \mathrm{~cm}^{-1}$ indicatesthe C-BR stretching presence of alkyl halides. The peak obtained at $1051.88 \mathrm{~cm}^{-1}$ indicate the C-N stretching confirm the presence of aliphatic amines. The peak obtained at $771.27 \mathrm{~cm}^{-1}$ indicates the $\mathrm{N}-\mathrm{H}$ bending presence of amines.

Among the functional groups observed in the extracts, $\mathrm{OH}$ group was found to be present uniformly only in the methanolic extracts. As $\mathrm{OH}$ group has got the ability of forming hydrogen bonding capacity, presence of $\mathrm{OH}$ group probably indicates the higher potential of methanolic extract towards inhibitory activity against microorganisms. So, FT-IR spectrum reflecting objectively the panorama of chemical constituents in complex system is a most credible method to validate and identify the mix-substance systems such as traditional medicine and herbal medicine
(Liu et al., 2006). The results of the present study spectrum also revealed the functional constituents present in the crude powder of A. neriifolia hook.

\section{Acknowledgment}

The authors are highly thankful to St.Joseph College, Tiruchirappalli for analysing FT-IR spectroscopic techniques for our study.

\section{References}

Agbor, A.G., Ngogang, Y.J. 2005. Toxicity of herbal preparations. Cam. J. Ethnobot., 1: 23-28.

Chaturvedi, N., Gupta, P., Shukla, k. 2015. Free radical scavenging and antioxidant activity of underutilized processed Jack bean (Canavalia ensiformis) and Barnyard millet (Echinochloa frumentacea) flour extract. Int. J. Pharm. Pharma. Res., 4(2): 24-34.

Griffiths, P.R., De Haseth, J.A. 1986. Fourier transform infrared spectroscopy. New York: Wiley. Helm, D., Labischinski, H., Schallehn, G and Naumann. D., (1991). Classification and identification of bacteria by Fourier transform infrared spectroscopy. $J$. Gen. Microbiol., 137: 69-79.

Herin Sheeba Gracelin, D., John De Britto, Benjamin Jeya Rathna Kumar. 2013. Qualitative and quantitative analysis of phytochemicals in five Pteris species. Int. J. Pharm. Pharma. Sci., 5(1): 105-107.

Liu, R.H., Hotchkiss, J.H. 1995. Potential genotoxicity of chronically elevated nitric oxide: a review. Mutat. Res., 339: 73-89.

Nithya Narayanaswamy, Balakrishnan. K.P. 2011. Evaluation of some medicinal plants for their antioxidant 
properties. Int. J. Pharm. Tech. Res., 3(1): 381-385.

Nithyadevi, J., Sivakumar, R. 2015. Phytochemical Screening and GCMS, FT-IR Analysis of Methanolic Extract Leaves of Solanum torvum Sw. Int. J. Res. Studies in Biosci., 3(9): 61-66.

Puguh Surjowardojo, Sarwiyono, Imam Thohari, Aswah Ridhowi. 2014. Quantitative and qualitative phytochemicals analysis of Muntingia calabura. J. Biol. Agri. Healthcare, 4(16): 84-88.
Roberts, J.K., M., Xia, J.H. 1995. High Resolution NMR Methods for study of higher plants. Method Cell Biol., 49: 245-258.

Sowndhararajan, K., Siddhuraju, P., Manian, S. 2011. Antioxidant activity of the differentially processed seeds of jack bean (Canavalia ensiformis L. DC). Food Sci. Biotechnol., 20(3): 585-591.

Tiwari, T.N., Pandey, V.B., Dubey, N.K. 2002. Plumieride from Allamanda cathartica as anantidermatophytic agent. Phytother. Res., 16(4): 393394.

\section{How to cite this article:}

Sumathi, R., and Anuradha, R. 2016. FT-IR Spectroscopic Studies on Flowers of Allamanda neriifolia Hook. Int.J.Curr.Microbiol.App.Sci. 5(6): 287-291. doi: http://dx.doi.org/10.20546/ijcmas.2016.506.032 